\title{
AS CIÊNCIAS SOCIAIS \\ NOS ÚLTIMOS 20 ANOS: \\ Três Perspectivas
}

Elisa Pereira Reis

Fábio Wanderley Reis

Gilberto Velho

As ciências sociais vão bem?

Elisa Reis - Tentarei responder de forma bastante esquemática, já que seria mesmo impossível contemplar todas as nuances pertinentes. Assim, vou me limitar a três observações. A primeira delas tem sinal positivo. Eu diria que sim, as ciências sociais vão bem no Brasil e no mundo, se o critério de avaliação for a magnitude e a urgência das questões com que elas se defrontam no presente. Em certo sentido essa afirmação não passa de um lugar comum, já que as ciências sociais, desde sua constituição, sempre se viram às voltas com problemas urgentes, situações de crise etc. No entanto, gostaria de ressaltar que a grande perplexidade do momento é acrescida pelo fato de que muitos dos termos, dos conceitos fundantes das ciências sociais, perderam sua centralidade ou passaram a competir com uma série de outros na estruturação das próprias disciplinas. Assim, assistimos a uma grande disputa no interior dessas ciências, disputa essa que é tanto intelectual quanto institucional. $\mathrm{Na}$ minha opinião, essa própria disputa deve ser vista como indicativa da vitalidade das ciências sociais.

A segunda observação diz respeito às ciências sociais no Brasil, especificamente. Eu diria que sim, elas vão bem se levarmos em conta que somos um corpo de profissionais que cresceu muito nos últimos 20 anos; que formamos cada vez mais mestres e doutores; que publicamos muito mais, e que nos tornamos uma comunidade científica mais complexa, mais diversificada, mais plural.

A terceira e última observação também é restrita ao contexto nacional, mas agora com sinal negativo. Eu diria que em virtude da situação peculiar que a universidade brasileira vive hoje, há razões para preocupação e incerteza. Dados os constrangimentos internos e externos com que se deparam nossas estruturas acadêmicas, é possível que a formação de novas gerações de cientistas sociais se veja seriamente comprometida.

Fabio W. Reis - É uma questão difícil, por tratar-se de tema muito vasto. É possível, entretanto, dizer que tem 
havido certo desenvolvimento. No que se refere aos campos e temas que são objeto de estudo, houve progresso em termos de incorporação de certas áreas temáticas. $\mathrm{Na}$ esfera política, por exemplo, há temas novos, que até há pouco tempo não eram tocados: a área institucional em geral, o judiciário, o legislativo, que têm sido tratados em uma perspectiva de Ciência Política, e não apenas na perspectiva jurídica tradicional. Da mesma forma, podem ser lembrados os estudos relacionados com o processo eleitoral, que também progrediram muito nos últimos 30 anos. Além disso, mais recentemente tem havido esforços novos, em diversas instituições, com respeito a uma área que foi negligenciada durante muito tempo, a das relações internacionais. $\mathrm{Na}$ esfera das outras disciplinas, me ocorre destacar os esforços feitos no campo dos estudos sobre criminalidade e violência. Estes são alguns exemplos de campos ou áreas temáticas em que houve efetiva ocupação de espaços e avanço nesses termos.

No plano teórico-metodológico, contudo, a avaliação que faço é muito mais restritiva e reservada. Tem-se um processo que, me parece, é negativo. Há um certo empobrecimento ou banalização dos critérios que guiam o trabalho na área, com o predomínio de uma postura descritiva ou "idiográfica", de cunho jornalístico, historiográfico, etnográfico... Naturalmente, numa descrição completa do quadro que temos no momento seria preciso matizar isso; quer dizer, nós certamente temos gente que aprendeu certa canônica básica e que é, em geral, responsável pelo que acontece de positivo em diversas áreas. Mas tenho a impressão de que o grosso do treinamento que está sendo dado aos nossos estudantes, mesmo no nível da pós-graduação, deixa claramente a desejar neste aspecto. Acho que é mesmo possível dizer que temos piorado, já que no início houve um compromisso, na pós-graduação pioneira em Ciência Política, com certo treinamento de tipo mais canônico, mais preocupado com o problema teórico-metodológico, mais analiticamente orientado. Estas, me parece, são as palavras-chave: orientação analiticamente exigente, engajamento teóricometodológico, por contraste com um descritivismo pobre e às vezes contente com sua pobreza.
Outro aspecto é o relacionado com o ensino de metodologia e técnicas de pesquisa nos programas de pósgraduação. Embora sempre conste alguma disciplina de metodologia entre as disciplinas ministradas, ela nunca chega a ter uma posição realmente central. Isso pode ser verificado nos diferentes programas. Os dois programas de maior visibilidade e prestígio nos campos da Sociologia e da Ciência Política — o da USP e o do Iuperj — não têm incluído essa disciplina no currículo obrigatório exigido dos estudantes. No caso da USP a situação é inequívoca, não tendo havido nunca a oferta regular de metodologia entendida como disciplina fundamental e obrigatória.

O resultado geral é que a situação atual se caracteriza por deficiências importantes, ressaltando a feição "historicizante" ou mesmo "jornalística" que tende a exibir o trabalho executado por nossos cientistas sociais. Com freqüência o trabalho empírico dos cientistas sociais brasileiros dificilmente pode ser distinguido do trabalho do historiador - exceto, talvez, pela precária qualidade da historiografia produzida, já que falta aos nossos profissionais o treinamento específico. Também são freqüentes trabalhos que realizam uma espécie de "historiografia do presente", caracterizada pelo empenho de registro jornalístico dos eventos. Como não há orientação analítica precisa ou indagações teóricas claras, o que é típico é que o pesquisador tome uma espécie de "pedaço" da realidade (o PT, os militares em tal período, os empresários paulistas) e procure levantar "tudo" o que diz respeito a esse "pedaço". O papel do pesquisador consiste, então, em contar o que leu em jornais velhos ou documentos de qualquer natureza - ou então, numa variante muito importante, em contar o que lhe foi dito em entrevistas mal processadas, com o pesquisador abdicando em favor de suas fontes e sendo "engolido" por elas, na descrição de Luiz Felipe de Alencastro. As perguntas que normalmente orientam tais trabalhos são do tipo "o que aconteceu?" ou "como aconteceu?", nunca do tipo "por quê?".

Quando se trata de temas da atualidade ou do passado recente, esta perspectiva tende a exibir a lógica da investigação detetivesca, buscando desvendar o "oculto". O 
fundamental não é o enquadramento analítico adequado de determinado fenômeno ou o esclarecimento de seu caráter de caso ou instância de uma regularidade que pode ser apreendida como tal, mas antes o acesso à fonte privilegiada. Mas, devido à pobreza analítica, o interesse da investigação vai depender inteiramente do interesse propriamente detetivesco ou jornalisticamente "quente" da informação trazida. A conseqüência é que este modelo de pesquisa, quando executado por cientistas sociais, acaba por produzir resultados que não têm sequer interesse jornalístico real, já que (ao contrário do jornalista, que cultiva profissionalmente as suas fontes) é raro que o cientista social tenha acesso a fontes efetivamente "quentes".

Mas talvez a cara mais saliente dos problemas que vejo seja a hegemonia de uma perspectiva que se apresenta como antropológica ou etnológica e que assim pretende validarse como abordagem peculiar e com méritos próprios. $\mathrm{O}$ resultado é que a pobreza analítica aqui se torna explicitamente autocomplacente, contente consigo mesma e até militante. Essa hegemonia fica bastante clara quando se examinam, por exemplo, as premiações da Anpocs no concurso anual de teses e obras científicas. Há um nítido predomínio de trabalhos de Antropologia, seja trabalhos que correspondem formalmente à Antropologia como disciplina, seja trabalhos formalmente de outras disciplinas mas que se dizem adeptos da abordagem etnológica. $\mathrm{Na}$ última vez em que participei do comitê de pesquisas da Anpocs, creio que em 1995, nada menos de 80\% dos projetos aprovados podiam ser classificados como de Antropologia. Na minha maneira de ver, esse predomínio da Antropologia se deve a um certo "facilitário", ao fato de que a Antropologia permitiria vender como legítima uma postura que envolve uma disposição passiva e supostamente "despojada" diante do objeto, mas que resulta ser antinomológica e antiteórica e redunda, na verdade, de novo na abdicação por parte do analista. Acho reveladora, por exemplo, a freqüência com que, no comitê de pesquisas da Anpocs, a defesa de determinado projeto era feita com base no argumento de que o grupo em questão nunca havia sido estudado. Isso bastaria para qualificar um projeto como bom, ainda que seja absolutamente banal do ponto de vista das questões que coloca. Nesta perspectiva, tornam-se irrelevantes questões de maior alcance, como, por exemplo, até que ponto o estudo proposto vai além do registro etnográfico ou pode vir a fornecer respostas passíveis de algum tipo de generalização, ou seja, respostas para perguntas de natureza e alcance teóricos.

Com o que estou dizendo não pretendo, naturalmente, reduzir a metodologia das ciências sociais ao uso desta ou daquela técnica específica, o survey por exemplo. Mas defendo, sim, que não podemos abrir mão de um modelo de ciência social decididamente comprometido com o rigor analítico e de vocação teórica e nomológica, empenhado na obtenção de um conhecimento passível de ser formulado em termos genéricos e eventualmente articulado em sistemas abstratos.

Essa perspectiva, no que se refere à maneira de conceber as relações entre as ciências sociais e as ciências exatas ou naturais, sustenta que o método científico é inequivocamente aplicável ao campo dos fenômenos humanos e sociais. Portanto, ela se opõe à idéia de uma contraposição irremediável entre "duas culturas", uma humanista e outra científica, e se coloca em favor da suposição de afinidade entre as ciências naturais e sociais quanto aos problemas básicos do método - entendendo a expressão como dizendo respeito aos fundamentos lógicos da aceitação ou rejeição de hipóteses ou teorias. A contraposição entre duas culturas tem certa correspondência com as diferenças entre disciplinas no próprio campo das ciências sociais, e é bem claro que ela está subjacente ao desconforto que estou manifestando, por exemplo, quanto à invasão das ciências sociais brasileiras pela Antropologia. Creio que a Sociologia e a Ciência Política encontram-se claramente mais próximas do padrão "científico", caracterizado pelo apego ao rigor, à sistematicidade, à generalização e à busca de cumulatividade, ao passo que a Antropologia e a História estariam, em geral, mais próximas do padrão "humanista" e "idiográfico" de trabalho, com a ênfase no qualitativo e no descritivo, a valorização da dimensão temporal ou histórica 
dos fenômenos e de suas conseqüentes "peculiaridades", o relativismo, a confiança depositada na intuição e na "compreensão".

Gilberto Velho - As ciências sociais são um mundo vasto e heterogêneo, com desníveis e contradições. Não dá para generalizar. Existem áreas e linhas criativas e inovadoras, ao lado de outras mais estagnadas e repetitivas. A interdisciplinaridade pode ser um caminho fértil caso não se banalize. No entanto, o excesso de especialização tende a constituir blocos fechados e paroquiais.

\section{O desenvolvimento da pós-graduação e da pesquisa em ciências sociais}

Elisa Reis - Talvez eu possa partir da observação informal que foi feita de que Fábio e eu "invadimos" um pouco o terreno um do outro, com observações sobre a Sociologia no caso dele e sobre a Ciência Política no meu caso. É que nós dois somos de uma geração em que a distinção entre estas disciplinas era ainda muito tênue. Eu acho que, ao longo desses 20 anos de Anpocs, houve uma diferenciação notável, um descolamento progressivo das duas disciplinas. Se pensarmos na origem da Anpocs, era muito mais difícil diferenciar as duas comunidades do que é hoje. Hoje em dia já existe uma diferenciação institucional mesma. Essa pode ser evidenciada na definição dos programas de pós-graduação, nas linhas de pesquisa, na bibliografia das publicações de uma ou outra dessas disciplinas, coisa que não acontecia antes.

Creio que a separação entre as disciplinas sociais — as três que a Anpocs contempla — é fruto da institucionalização profissional. Quanto mais se institucionaliza a profissão, mais fácil torna-se identificar as diferenças entre as disciplinas. No caso dos Estados Unidos e da Europa, ninguém tem dúvidas quanto à identidade distintiva de cada uma delas. Aqui ainda temos vestígios de sobreposição entre a Sociologia e a Ciência Política. De qualquer forma, a maturidade do sistema de pós-graduação a que assistimos ao longo do período sobre o qual estamos falando sugere claramente uma separação maior entre as duas disciplinas.

Já em relação à Antropologia, eu penso que ela sempre teve uma especificidade maior, por razões históricoinstitucionais do Brasil. A Antropologia e a Sociologia são mais ou menos contemporâneas nos nossos programas acadêmicos, ao passo que a Ciência Política, como disciplina, aparece muito mais tarde. Por isso ela foi tão tributária da Sociologia.

É importante salientar que a simbiose tradicional entre a Sociologia e a Ciência Política expressa também, de fato, uma comunalidade de interesses de pesquisa. Isso é, embora a Sociologia seja, de uma certa forma, vista como a mãe de todas as ciências sociais, a verdade é que a Sociologia brasileira no passado era mais politizada do que é hoje. O predomínio da Sociologia Política no passado era muito grande. Hoje, até porque se criou um canal específico para os estudos sobre a política, a Sociologia não é mais tão marcadamente uma Sociologia Política como ela era. É claro que tudo isso precisa ser visto sem exageros. Sempre tivemos cientistas sociais mais afinados com a análise política e creio que sempre teremos pessoas, como o Fábio Wanderley e como eu mesma, que ainda estão muito dentro do recorte da Sociologia Política.

Em resumo, o quadro que comentei é parte da história das ciências sociais no Brasil, e ao longos dos últimos 20 anos a Anpocs foi um agente importante nessa progressiva institucionalização da autonomia disciplinar. Restaria comentar ainda o movimento inverso de implosão das fronteiras disciplinares, movimento que é tão acentuado hoje. Mas, para não me alongar demasiado, eu diria apenas que podemos ver esse processo como a gestação de novas especializações disciplinares.

Ao longo dos últimos 20 anos caminhamos muito, consolidamos muita coisa. Lutamos juntos contra muita coisa e, nesse momento, o quadro se alterou. Quer dizer, não há dúvidas de que temos algumas dificuldades em comum, mas não temos mais um grande inimigo comum. Esse é um primeiro aspecto do impacto da democratização 
nas próprias instituições das ciências sociais. Um outro aspecto importante é que temos muito mais instituições e pesquisadores competindo por recursos. Como não houve uma ampliação tão significativa dos recursos, somos mais atores competindo pelos recursos disponíveis. Assim, o que às vezes parece desestruturação é, de fato, uma saudável vitalidade da comunidade. Acho que parece desestruturação pelo próprio fato de que estávamos muito "estabelecidos" como instituições. Vivemos um processo de crescimento, maturação, consolidação. Grande parte dos programas de ensino e pesquisa podiam se dizer consolidados, e aí começaram a surgir novos atores na arena. Durante algum tempo fomos um número fixo de parceiros. Claro que houve sempre crescimento, ampliação, mas, de uma certa forma, o jogo se consolidou com um número determinado de parceiros. A entrada de novos competidores desestabiliza o jogo, o que não quer dizer que quem estava jogando antes vai necessariamente perder. $\mathrm{O}$ fato é que as regras são mais ou menos as mesmas, mas as mesmas regras com um número maior de competidores geram resultados diferentes.

A verdade é que quanto mais bem institucionalizado está o sistema de pós-graduação e pesquisa, mais a entrada de novos competidores e a introdução de inovações no sistema vão provocar desconforto para atores já consolidados. Eu acho que nos compete ter lucidez para entender que continuamos sendo jogadores aptos, que o jogo vai continuar.

Fabio W. Reis - A implantação inicial da pós-graduação, que foi um importante ponto de inflexão no processo de desenvolvimento das ciências sociais no Brasil, ocorreu num momento em que o panorama internacional das ciências sociais (especialmente a Sociologia e a Ciência Política) estava marcado pela afirmação recente, particularmente nos Estados Unidos, de uma perspectiva comprometida com o objetivo de constituir uma ciência rigorosa da sociedade. No campo da Sociologia, havia o recurso crescente a métodos quantitativos e rigorosos, o desenvolvimento das técnicas de survey, o empenho em estabelecer correspondência entre a reflexão teórica e o trabalho de pesquisa empírica, realizados de forma sistemática e cumulativa. No campo da Ciência Política, as tradicionais abordagens de orientação filosófica e jurídica eram vigorosamente desafiadas pelo movimento que se tornou conhecido como behavioralism, no qual se incorporavam à disciplina muitos dos mesmos traços que ocorriam na Sociologia.

No Brasil, inaugura-se então, como parte da movimentação que resulta na implantação da pós-graduação em ciências sociais, uma fase de intenso intercâmbio internacional. Há grande afluxo de estudantes a programas de pós-graduação, primeiro na Faculdade Latino-Americana de Ciências Sociais (FLACSO) e, posteriormente, em universidades européias e, em especial, norte-americanas. Assim, a construção da pós-graduação brasileira incorpora inicialmente o impulso renovador e o empenho de apuro teórico e metodológico que se davam nos centros mais avançados.

Dois centros brasileiros exemplificam melhor essa tendência: o Departamento de Ciência Política da UFMG e o Instituto Universitário de Pesquisas do Rio de Janeiro (Iuperj), que iniciam na década de 60 programas de mestrado em Ciência Política e Sociologia, contando com importante apoio da Fundação Ford. Eu diria que essas duas instituições procuravam mais claramente colocar em prática o modelo de ciência social que defendi antes.

Contudo, apesar dessa dinâmica inicial da implantação da pós-graduação, que se ilustra com os casos do DCP-UFMG e do Iuperj, essa perspectiva "científica" não chegou a amadurecer efetivamente e a constituir-se em ortodoxia real no Brasil. Ao contrário, ela sofreu prontamente uma poderosa reação proveniente de pelo menos duas fontes. Uma diz respeito às resistências político-ideológicas. A perspectiva "científica" aparece aqui como comprometida com a direita política, o que se expressaria em seus vínculos com o establishment acadêmico dos Estados Unidos e no apoio recebido, no Brasil, da Fundação Ford, vista como agente do imperialismo norte-americano. A segunda fonte, que é mais ou menos independente do enfrentamento político entre esquerda e direita, tem a ver com o apego de 
parcela importante dos cientistas sociais brasileiros ao padrão humanista e idiográfico de trabalho.

O que fazer para superar as deficiências que têm marcado o desenvolvimento das ciências sociais no Brasil? A principal dificuldade para responder a essa pergunta está na própria natureza do diagnóstico feito das deficiências, que se refere a um problema de qualidade do treinamento que vem sendo dado aos estudantes e do trabalho que, em geral, vem sendo produzido. Assim, o ataque adequado a esse problema contrapor-se-ia de maneira muito frontal aos rumos assumidos pela evolução recente da ciência social estabelecida no país e a suas diretrizes ao menos tácitas. $\mathrm{Ou}$ seja, seria preciso nadar contra a corrente. É claro que o meu diagnóstico não vai ser compartilhado por muitos dos que têm assento nos órgãos com capacidade de tomar decisões. Em termos concretos, a recomendação principal é, de certa forma, banal; trata-se de um peixe que venho tratando de vender há mais de 30 anos: fortalecer a qualidade do treinamento teórico-metodológico, em termos que valorizem o modelo analítico e sistemático do trabalho científico.

Mas há um aspecto específico que merece destaque: precisamos manter a formação de pessoal no exterior. Não podemos dispensar a exposição direta e sistemática de nossos estudantes aos desenvolvimentos mais recentes e aos debates de fronteira no interior da disciplina. Acho equivocada a diretriz que vem sendo adotada pelas agências de financiamento em relação à concessão de bolsas para o exterior: é um erro restringir a bolsa de doutorado completa no exterior (restrição que não tem prevalecido, aliás, na área da Economia). A bolsa sanduíche não é um substituto adequado, pois o tipo de exposição, de desafio, de formação que se pode ter com um programa extenso, particularmente nos Estados Unidos, não é suprido com a bolsa sanduíche, com a flexibilidade descompromissada que a caracteriza e que permite que se passeie de um lado para outro sem as exigências e responsabilidades da submissão formal às regras das universidades para o treinamento sistemático.
Considero também, nesse mesmo sentido, que qualquer iniciativa para minorar nossa deficiência no treinamento em metodologia, como a proposta do $\mathrm{CNPq}$ de financiar cursos regulares de metodologia em universidades estrangeiras, é bem-vinda. Insisto em que isso não significa impor uma certa maneira de entender o problema de método, especialmente o recurso a certas técnicas específicas. Na condição atual das ciências sociais, é preciso reconhecer que o profissional da área pode chegar a aderir madura e sofisticadamente, em fases avançadas de seu desenvolvimento pessoal na profissão, a diferentes escolhas metodológicas. Mas a pobreza que caracteriza o treinamento e o debate teórico-metodológicos do momento nas ciências sociais brasileiras certamente não justifica esperar esse resultado. Portanto, a alegação de que existem muitas abordagens e perspectivas possíveis acaba representando uma fuga ao debate real entre pontos de vista e uma irresponsabilidade quanto à adequada exposição do estudante a certo feijão-com-arroz no treinamento básico.

Gilberto Velho - O desenvolvimento da pós-graduação, em termos de um modelo novo de mestrado e de doutorado, foi absolutamente fundamental para o amadurecimento da pesquisa científica como um todo no Brasil. Especificamente, a nossa área de Antropologia apresentou um salto muito significativo. Nesse sentido, a introdução de um modelo de pós-graduação que de certa maneira adaptava o formato institucional de outros países - principalmente dos Estados Unidos - acabou se constituindo em um estímulo absolutamente crucial para que a pesquisa propriamente dita também desse um salto.

Esse processo ocorreu de modo paradoxal, pois, de certa forma, foi durante o regime militar que o modelo se formalizou. Quer dizer, o início dessa alavancagem nas ciências sociais deu-se certamente no regime militar, em parte vinculado ao apoio de instituições ou de agências estrangeiras (como no caso da Fundação Ford, que financiou centros, linhas e grupos de pesquisa), assim como, mais adiante, da Financiadora de Estudos e Projetos (Finep), uma agência do governo federal que veio ocupar um espaço novo. Agora, no início de agosto, completaram- 
se 30 anos de apoio, quando esta última agência veio juntarse a outras mais tradicionais, como o CNPq e a CAPES. Esse tipo de apoio institucional foi para muitos grupos absolutamente básico, já que permitiu o desenvolvimento de atividades integradas de pós-graduação e pesquisa. Esse é, com efeito, o aspecto mais importante a ser destacado: as atividades de pós-graduação e de pesquisa devem estar vinculadas, ou melhor, uma servindo à outra.

Em alguns lugares esse passo foi dado com maior sucesso; em outros, com menos. Existiam pós-graduações anteriores a esse momento, mas que também foram afetadas positivamente por essas transformações, sendo que já no final dos anos 60 temos alguns centros recebendo, primeiro o apoio da Ford e, depois, nos anos 70, da Finep. De qualquer forma, existia e ainda existe uma preocupação geral de regularizar a pós-graduação, de sistematizá-la, enfim, de torná-la uma área de excelência.

Não há a menor dúvida, hoje em dia, de que a pósgraduação no Brasil tornou-se uma área de excelência. Muita coisa pode ser dita a respeito, mas o que me parece importante destacar nesse momento é que, apesar dos ganhos, vivemos uma crise financeira alarmante, que ameaça essa excelência.

Os centros de pesquisa têm desempenhado o papel de pólo dinâmico na vida acadêmica brasileira, vinculados direta ou indiretamente à pós-graduação. A universidade tem uma relação ambígua com esses centros. Atualmente ela até retira recursos dos centros de pesquisa para enfrentar suas dificuldades mais imediatas. As taxas de bancada, por exemplo. É sabido que taxas de bancada dos programas de pós-graduação têm sido usadas para pagar despesas básicas da universidade, como luz e limpeza. Isso tudo porque a universidade não tem dinheiro, e não tem dinheiro porque o Ministério da Fazenda não libera verbas para o Ministério da Educação que, por sua vez, não pode, portanto, fornecer os recursos para as universidades. Resumindo: vivemos uma situação muito precária. Mas é preciso reconhecer os avanços, de um modo geral, existentes na sociedade brasileira com a estabilidade do Plano Real.
No entanto, essa concepção do que deva ser estabilidade econômica - com as conseqüências disso em termos da política pública em geral — acaba afetando vários níveis do governo, vários níveis do setor público. O setor de saúde é o mais conhecido e o mais divulgado em termos de crise, e das dificuldades que afetam a população. Mas a situação da universidade (e estou falando também da pós-graduação e da pesquisa) certamente é das mais sérias.

Por outro lado, parece-me que as relações interinstitucionais têm melhorado e vem ocorrendo um evidente avanço. Por exemplo, o Programa de Núcleos de Excelência (Pronex) - do qual sou coordenador, atualmente, da área de Ciências Humanas e Sociais, na comissão geral — tem estimulado o intercâmbio entre instituições universitárias diferentes, entre departamentos diferentes, entre institutos diferentes. A situação está muito longe do ideal, mas acredito que já existe possibilidade de elaborar meios e instrumentos que nos levarão a sair do campo da simples declaração de intenções ou dos contatos apenas individuais e esporádicos. Em minha opinião, o Programa de Núcleos de Excelência tem como uma de suas metas, exatamente, permitir isso: facilitar aproximações e sistematizar intercâmbios.

No CNPq, com os projetos integrados, essa possibilidade está também, em princípio, dada. Existe, porém, a crucial questão dos recursos. Parece que os projetos integrados do $\mathrm{CNPq}$ sofreram muito com o atraso de recursos. Dessa maneira, a despeito dos contratempos, em termos de perspectiva de atuação coordenada — juntando instituições diferentes, profissionais de diferentes áreas e departamentos — a situação tende a melhorar.

\section{Relações com a comunidade científica internacional}

Elisa Reis - Vamos começar pela América Latina. Claro que essa é uma visão muito pessoal e que existem muito mais esforços de interação e de integração do que os que eu 
conheço. Mas, na minha percepção, o Brasil tem uma certa vocação isolacionista em relação à América Latina. Acho isso até certo ponto compreensível. É um pouco fruto da dimensão continental do país, apesar de que a Índia também é continental e, no entanto, dialoga tanto e publica tanto fora de suas fronteiras. Claro que há uma diferença fundamental: eles publicam em inglês e, por isso, já estão, de saída, em posição mais favorável no mercado mundial. É preciso também qualificar essa observação, pois se é verdade que os cientistas sociais indianos interagem mais que nós com a ciência social internacional, isso não se aplica à maioria. Se observarmos o vasto sistema universitário da Índia, veremos também que a dinâmica interna do sistema faz com que grande parte da produção seja muito fechada em si mesma.

No Brasil, sem dúvida alguma, temos alguma dificuldade nesse sentido. Apesar da grande próximidade com a língua espanhola, não temos tanto estímulo para interagir com a América Latina. Isso mudou um pouco nos anos 60. Até o fim da década de 60, o Chile era um pólo de irradiação em ciências sociais na América Latina. A Faculdade LatinoAmericana de Ciências Sociais (FLACSO), que foi a pioneira dos programas de pós-graduação na América Latina, cumpriu um grande papel integrador. Havia ainda a Escolatina, o ILPES, o CELADE, todos localizados no Chile. Essa concentração tinha a ver, sobretudo, com a estabilidade política, com a tradição democrática do Chile.

Isso acabou com a onda autoritária dos anos 70. O Chile deixou de ser democrático e eu acho que nessa fase de declínio da hegemonia hispânica nas ciências sociais o Brasil foi ganhando maior peso. $\mathrm{O}$ que eu estou caracterizando como chileno era a vocação cosmopolita, porque todos esses programas eram programas internacionais. Antes disso a Argentina já contava com uma produção em ciências sociais digna de destaque, mas que começou a sofrer os efeitos do autoritarismo muito mais cedo do que nós no Brasil. No começo dos anos 60 a Argentina estava experimentando levas de emigrações de cientistas sociais e, naturalmente, o sistema universitário começou a ser desmantelado. O México sempre teve uma produção digna de nota, mas não sei se pela proximidade dos Estados Unidos e a distância do Brasil, o fato é que havia — e há até hoje — pouca interação.

Com a implantação do sistema de pós-graduação nas universidades brasileiras nos anos 70, o Brasil assumiu mais e mais um papel relevante na formação de mestres e doutores. A introdução de programas formais de mestrado e doutorado em outros países latino-americanos é muito posterior e, em muitos casos, ainda não aconteceu. Creio que existe pouca integração, mas mesmo assim preciso qualificar isso. Estou pensando no grande número de alunos latino-americanos que nossos programas no Brasil têm formado - temos formado argentinos, uruguaios, paraguaios, peruanos, bolivianos etc. Creio que temos tido uma contribuição importante na formação de pesquisadores e professores universitários que retornam a seus países de origem.

O interesse de certos países latino-americanos por nossos cursos de pós-graduação é enorme e está crescendo. Não temos ainda uma visão de conjunto, e acho que a questão está merecendo um estudo: o impacto dos programas de pós-graduação e pesquisa no Brasil junto aos países da América Latina.

Nas atividades de pesquisa tem havido menos parceria. Aí existem dificuldades recíprocas no que diz respeito à comunicação, aos recursos financeiros e outros. Claro que há exceções. Por exemplo, os estudos sobre democratização - primeiro, transição democrática e, depois, consolidação democrática. Aí acho que houve um esforço notável de integrar pesquisadores de diferentes países latino-americanos. De qualquer forma, de uma maneira geral as iniciativas são ainda muito experimentais. É muito difícil encontrar uma pesquisa comparativa sistemática envolvendo pesquisadores latino-americanos. O mais comum são coletâneas de estudos de caso. Desenhos comparativos de pesquisa praticamente inexistem no Brasil e em outros países da América Latina.

Para mim, esse é um dos desafios mais interessantes com que nos confrontamos hoje. Comparar, por exemplo, os processos de mobilidade nos anos 80 no Chile e no Brasil. 
Começam a surgir algumas iniciativas que podem contribuir de forma significativa nesse sentido. Penso, por exemplo, no esforço já iniciado no âmbito do Mercosul para trocar experiências, padronizar as políticas de pósgraduação etc.

Também na relação com os Estados Unidos, acho que há uma questão temporal que merece ser contemplada. Se pensarmos em meados dos anos 60, mas sobretudo nos anos 70 , um número enorme de pesquisadores brasileiros foi treinado nos Estados Unidos. Já é lugar-comum dizer que nesse período houve uma reorientação acentuada, substituindo-se a Europa pelos Estados Unidos como pólo de influência nas ciências sociais brasileiras, e não preciso repetir essa história. O fato é que a criação dos programas de pós-graduação no Brasil, na sua origem, foi muito marcada pela experiência das pessoas treinadas nos Estados Unidos, pessoas que fizeram o mestrado ou o doutorado fora. Nosso modelo guarda até hoje muita proximidade com o americano.

Isso sempre tem de ser qualificado, porque também nunca jogamos fora nossa própria tradição intelectual, por um lado, e nossa experiência de interação com a Europa, por outro. Assim, por exemplo, devagarzinho, a experiência de ser treinado na França foi sendo recuperada também. Acho que nossa reflexão ficou um pouco parada no tempo e continuamos repetindo longamente a história do peso avassalador do treinamento nos Estados Unidos. $\mathrm{Na}$ verdade a história não é bem assim. Se examinarmos os dados, veremos, por exemplo, que o número de cientistas sociais que vai estudar na França é muito alto. $\mathrm{O}$ número de pessoas formadas na Inglaterra também. Acho que nesse aspecto a experiência brasileira tem sido bastante pluralista.

O que me preocupa é uma certa preferência, que identifico com freqüência na comunidade, por internalizar totalmente a formação dos cientistas sociais: essa idéia de que o Brasil já consolidou um programa de doutorado, que já não precisamos mais mandar gente para fora, exceto em casos muito excepcionais. Vejo isso com muita preocupação. Por um lado, não há dúvidas sobre quão caro é manter um aluno estudando fora do Brasil. Não podemos correr o risco de errar na seleção porque o custo de treinar gente fora é realmente muito alto.

Por outro lado, acho que é essencial, fundamental, formar cientistas sociais fora do Brasil. Senão corremos o risco de cair em um paroquialismo, em um provincianismo muito grande. A afirmação mais ou menos corriqueira de que "é um absurdo mandar brasileiros estudar o Brasil longe do país" não me parece razoável. Acho, ao contrário, que é fundamental estudar o Brasil também de fora do Brasil. O risco que a gente corre é achar que aqui "temos uma dinâmica peculiar", que "temos de estudar os nossos problemas é aqui mesmo". Aí, o aluno motivado a estudar fora começa a inventar um projeto inviável no Brasil para poder justificar a necessidade de sair. Creio que há um equívoco nisso tudo. Temos de mandar alunos estudarem o Brasil lá de fora também para colocar o Brasil em perspectiva, e para que eles possam ser o contraponto aos que estudam o Brasil aqui de dentro.

Quanto às influências das relações com o exterior em nossos temas ou nossas teorias, minha opinião é a seguinte: influência, todo mundo exerce sobre todo mundo o tempo todo. Diz-se muito que o Brasil é referenciado para fora, mas a comunidade de cientistas sociais, de certa forma, é uma comunidade internacional. Compartilhamos muitas preocupações com colegas de outros países. Por exemplo, temas de grande popularidade no momento, como globalização. É claro que você pode dizer que isso chegou ao Brasil via Estados Unidos, chegou ao Brasil via Europa. Chega de todos os lados. A globalização é isso: nós todos influenciando uns aos outros o tempo todo. Acho que podemos nos postular como parceiros, de igual para igual, de cientistas sociais de outros países e juntos definirmos a nossa temática.

É claro que, por exemplo, a teoria sociológica tem mais produção, mais fontes de publicação, em outros contextos do que no nosso. Então, é natural que os modelos teóricos que nós discutimos, que nós passamos para os nossos alunos, sejam modelos, via de regra, muito mais vitalizados fora do Brasil do que aqui. A grande maioria da produção teórica em Sociologia continua sendo americana, francesa, 
inglesa, alemã. Não há dúvida. Isso se explica pela institucionalização da Sociologia, pela história das instituições acadêmicas daquelas sociedades. Outras nações européias não têm a mesma visibilidade teórica que têm os países que mencionei. Muitas vezes perdemos a dimensão das coisas e ignoramos que algumas Sociologias na Europa estão menos consolidadas do que a nossa.

Sobre a relação com a comunidade internacional no que diz respeito à pesquisa, comparativamente às outras ciências, creio que as ciências sociais ainda estão bastante isoladas. Há pouca gente trabalhando nesse front, em parte pelas razões que já apontei — temos muitos projetos de pesquisa "artesanais" e poucos projetos de equipe. Além disso, muita gente trabalha pensando na especificidade brasileira, e aî fica difícil comparar, porque parte-se do suposto de que o Brasil é diferente. Acho que isso está sendo aos poucos superado, mas durante muito tempo essa perspectiva foi dominante.

Fabio W. Reis - Se me pedem uma comparação geral do avanço e qualidade da ciência social feita no Brasil com a de outros países, creio que dá para dizer algo com respeito à Ciência Política. Creio que temos no Brasil maior institucionalização da pós-graduação e talvez até melhor produção (pelo menos no que temos de melhor...) do que, em geral, nos outros países da América Latina. Quanto à Europa, temos lá uma situação muito mais heterogênea. Acho possível dizer que a França praticamente não tem Ciência Política de maior interesse. Na Inglaterra há a tradição erudita e ritualista da political theory, que produz com abundância trabalhos agradáveis de se ler mas que me parece uma tradição predominantemente estéril. Os eternos comentários sobre os clássicos, o eterno voltar a Hobbes, Locke... De vez em quando alguém inventa uma nova leitura, como Macpherson fez algumas décadas atrás, e aí se produz uma abundante literatura secundária... $\mathrm{Na}$ Alemanha há uma importante revivescência, com nomes de estatura e contribuições de interesse em várias áreas. Mas os Estados Unidos são claramente o país onde de fato as coisas acontecem, e não há como deixar de destacar o seu papel, que tende mesmo a criar um forte efeito de gravitação e a incorporar de um jeito ou de outro o que aparece de melhor na Europa: um Brian Barry, um Jon Elster, um Adam Przeworski, que acabam por se estabelecer parcial ou totalmente por lá; um Habermas e um Claus Offe intensamente publicados, o primeiro cultivado em centros diversos... (Aliás, Offe conta num depoimento que foi nos Estados Unidos que ele acabou de descobrir o próprio Weber.) E a importância dos Estados Unidos se dá não só no que se refere à produção da disciplina vista de maneira mais convencional, mas também no plano das relações com outras disciplinas, que têm tido conseqüências extremamente dinâmicas e positivas, como é o caso, em particular, das relações com a Economia, com o forte impacto do estabelecimento e difusão da abordagem da escolha racional. A força desse impacto se mostra mesmo, aliás, de maneira meio surpreendente, na revivescência da própria filosofia política, claramente influenciada pelo impacto da perspectiva analítica básica que levou ao florescimento da escolha racional (a "welfare economics" etc.), como no caso da obra de John Rawls, por exemplo.

De qualquer modo, creio que não há dúvida de que o grosso de nossa ciência social fica bem longe do que se faz de melhor no plano internacional.

Mas a questão da qualidade comparativa se articula com certos aspectos de uma questão diferente, a da inserção internacional das ciências sociais brasileiras, onde podem estar algumas das razões das deficiências de qualidade. Essa inserção tem-se dado de acordo com um padrão de colaboração internacional estratificada e hierarquizada, no qual as expectativas de parte a parte (tanto as dos especialistas "centrais" quanto as nossas próprias) são as de que sejamos fornecedores de "matéria-prima" brasileira para as elaborações teóricas de grande alcance a serem feitas pelos cientistas sociais dos países desenvolvidos.

Um dos aspectos disso é uma atitude ritualística perante a teoria entre nós, em que ela é vista como algo "etéreo" e impropriamente "abstrato" e, de qualquer forma, como responsabilidade e prerrogativa dos cientistas sociais europeus e americanos. Assim, o trabalho teórico deixaria de ter ligação com os problemas reais enfrentados no 
trabalho de pesquisa e suas exigências metodológicas. A conseqüência inevitável é uma postura dependente e provinciana, em que temos ou a admiração basbaque diante da produção teórico-metodológica dos países centrais (com os profissionais nacionais reduzidos à condição de público espectador ou consumidor), ou o rechaço às "abstrações" da teoria em nome da "relevância", cujo critério crucial é o de que o trabalho esteja diretamente referido à "realidade", que é antes de mais nada a realidade brasileira. Nessa ótica, boa ciência social é aquela que, com alguma reverência aos modelos ou abordagens "quentes" do momento, se dirige a problemas empíricos e práticos prementes, os quais vêm a ser os problemas socialmente relevantes na sociedade em que vivemos. Omite-se, assim, a ponderação crucial de que não saberemos sequer definir com propriedade nossos problemas empíricos e práticos se não tivermos condições de refletir com sofisticação adequada a respeito deles, vale dizer, se não formos teoricamente sofisticados.

Há também uma espécie de manifestação contorcida desse padrão, embora os resultados no plano intelectual sejam semelhantes. Ao invés da reverência diante da produção dos cientistas sociais dos países desenvolvidos, o que se tem aqui é a preocupação com a relevância levando a um nacionalismo mais afirmativo: a ciência social internacional e os modelos, análises e teorias por ela elaborados (salvo certos casos especiais como, por exemplo, alguma corrente marxista com que o pesquisador se identifique) são desqualificados liminarmente como irrelevantes, dadas as "peculiaridades" ou "especificidades" brasileiras. E o projeto, explícito ou implícito, é o de criar uma ciência social genuinamente "brasileira"...

Qual a alternativa? Acho que é possível contrapor a esse nacionalismo provinciano, com sua referência eterna e imediata ao Brasil, a idéia de uma afirmação teóricometodológica de nossa ciência social, que tem como condição indispensável a de ser intelectualmente cosmopolita e aberta. Nessa perspectiva, muito mais importante do que o fato de que estaremos lendo o que se produz internacionalmente (coisa que, afinal, fazemos bastante avidamente em nosso provincianismo dependente) é o fato de que o Brasil, em vez de representar o horizonte e o contexto insuperável de enquadramento de nossa reflexão, se tornará um caso entre outros. Mesmo com a inevitável importância prática que tem para nós, o caso a que o Brasil corresponde não poderá constituir-se como tal e ser apreendido mesmo em sua especificidade e singularidade senão por meio de uma atividade que é necessariamente teórica, generalizante ou nomológica, analiticamente requintada, comparativa... Em vez de "narrar" singelamente o Brasil, ou a multiplicidade infinita de aspectos da vida brasileira, e de erigir no trabalho correspondente a indigência analítica em virtude, o desafio consiste em transformar, nas diferentes áreas de problemas, nosso fatal "contexto" brasileiro em variável, ou seja, explicitar as dimensões analíticas cuja articulação permitiria, no limite, dar conta de maneira parcimoniosa tanto daquilo que o configura como um caso particular quanto de outros casos que dele se afastam por alguns aspectos e se aproximam por outros.

As especificidades da Antropologia, com sua ênfase no esforço descritivo e a busca das "peculiaridades", levam à indagação de se não haveria particularidades também na sua inserção internacional. A questão é saber se esses traços caracterizam não a Antropologia brasileira, mas a Antropologia como tal. Pois, se assim for, então ela vai aparecer no próprio plano internacional como uma espécie de parente menos exigente e difícil das outras ciências sociais, com a conseqüência de que seria mais fácil para a Antropologia brasileira do que para a Sociologia e a Ciência Política ombrear com os melhores padrões de suas congêneres internacionais. Dado o peso da perspectiva descritivo-etnográfica no campo da Antropologia, teríamos um certo "nivelamento" internacional das práticas e tornarse-ia mais natural que se estabelecessem relações "paritárias" entre os especialistas do Primeiro e do Terceiro Mundos. Em contraste, nos campos da Sociologia e da Ciência Política, onde a desigualdade de recursos acadêmicos de toda ordem faz com que a vocação teórica e generalizante possa ser mais bem cumprida pelos especialistas do Primeiro Mundo, teríamos a tendência mais marcada a certa estratificação — na qual, como disse antes, os profissionais do Terceiro Mundo aparecem com 
freqüência como os fornecedores de "matéria-prima" para os especialistas "centrais".

Naturalmente, se os padrões de relacionamento internacional são efetivamente afetados por fatores como esses, temos um acúmulo especialmente perverso de circunstâncias conspirando contra o enraizamento de uma forma de trabalho analiticamente exigente e teoricamente ambiciosa na ciência social dos países subdesenvolvidos. Pois mesmo o reconhecimento internacional (embora conforme padrões estratificados) se torna mais fácil com o abandono das pretensões correspondentes a essa forma de trabalho, vista como prerrogativa dos cientistas sociais "centrais" ou como merecendo presunção em geral negativa quando executada por cientistas sociais dos países subdesenvolvidos. Assim, um sociólogo ou cientista político brasileiro tem boas chances de ter trabalhos seus aceitos para publicação na Latin American Research Review ou em Problèmes d'Amérique Latine, publicações nas quais supostamente se trata, por definição, de problemas "concretos" da região latino-americana; mas certamente vai ter dificuldades se tentar publicar nos Archives Européennes de Sociologie ou na American Political Science Review - e acho que é possível sugerir que essas dificuldades vão ser provavelmente maiores, por motivos meio espúrios, do que as encontradas pelos antropólogos brasileiros para publicação em periódicos de prestígio correspondente na área da Antropologia. Uma ramificação especial da questão é a da qualidade do trabalho executado pelos area specialists ou country specialists dos próprios países desenvolvidos em comparação com os demais profissionais de ciências sociais daqueles países, e, conseqüentemente, a do statusde que lá desfrutam no sistema social das ciências sociais: trata-se claramente, em muitos casos, de profissionais de segunda categoria (não obstante o prestígio de que costumam gozar em seu país-tema, como certamente se dá no Brasil). Mas, seja o que for que aconteça quanto a este último aspecto, provavelmente temos aqui certas articulações entre diversas facetas da questão geral nas quais se criam "nichos" ou "redes" especiais de interação e comunicação internacional paritárias que servem de proteção contra a competição mais dura em que se achariam envolvidos os praticantes da Sociologia e da Ciência Política.

Gilberto Velho - Existem vários níveis de relação. Em primeiro lugar, registrem-se os profissionais brasileiros que, em algum momento, tiveram parte, ou grande parte, de sua formação no exterior. Além disso, há um intercâmbio científico permanente. De um lado, temos pesquisadores estrangeiros que vêm ao Brasil para fazer trabalho de campo e concluir suas pesquisas, além de eventualmente ensinar e participar das discussões brasileiras. Porém, existe o outro lado: têm crescido a demanda e o interesse pela ida de profissionais brasileiros para o exterior. Não só professores brasileiros vão participar de congressos internacionais, como vários profissionais têm sido convidados por universidades e instituições estrangeiras para expor seus trabalhos, para falar de suas pesquisas e de sua produção. Essas iniciativas não são isoladas; são, na verdade, experiências muito significativas. Estou falando não só das comunicações mais tradicionais com países como Estados Unidos, Inglaterra e França, mas também de situações novas, dos inúmeros convites feitos pela Argentina, Portugal, Espanha, Holanda, Suécia. Parece-me que está mais aberta do que nunca a possibilidade de se estabelecerem intercâmbios nas duas direções, com vários países, com diferentes sociedades. Eu acho que não só estamos participando intensamente de um sistema internacional, como nossa posição é cada vez mais destacada.

Com relação à Antropologia brasileira, é preciso dizer que ela está muito bem posicionada em geral, e sobretudo em relação aos outros países da América Latina (com a possível exceção do México, que tem uma história de Antropologia bem particular). A Antropologia brasileira está mais consolidada e temos assumido uma certa liderança neste cenário. Existe, inclusive, uma demanda internacional nesse sentido. No Museu Nacional, por exemplo, a procura de estudantes de outros países é muito freqüente. Vários estudantes argentinos e de alguns países latino-americanos e africanos estão regularmente matriculados no nosso programa de pós-graduação. É claro que esta procura não ocorre só no Museu Nacional, mas lá, particularmente, a 
presença de estudantes argentinos é significativa. Alguns deles voltam para seus países e levam o que aprenderam; outros ficam aqui e têm uma participação importante nessa Antropologia brasileira.

A produção dos antropólogos brasileiros tem um peso internacional muito grande. $\mathrm{Eu}$ não quero fazer comparações, porque talvez nem conheça suficientemente a situação das outras áreas. O que sei é que a Antropologia certamente tem tido uma repercussão muito grande, por intermédio de obras individuais, de autores, e dos esforços coletivos de pesquisa de seus grupos e de suas instituições.

Existem também acordos e relações com universidades de fora do país, por meio de diferentes programas. No caso do Museu Nacional, existe cooperação com várias instituições dos Estados Unidos, Inglaterra, França, Portugal e Argentina. Eu sei que outras instituições brasileiras também têm mantido esse tipo de contato, o que revela como as ciências sociais no Brasil estão longe do isolamento e procuram relações mais paritárias. O apoio da CAPES, do $\mathrm{CNPq}$ e das agências internacionais tem sido fundamental e pode ser aperfeiçoado.

\section{Áreas temáticas e abordagens metodológicas}

Elisa Reis - No caso da Ciência Política, acho que é relativamente fácil identificar áreas temáticas predominantes ao longo dos últimos 20 anos. Eu diria que os temas políticos nacionais predominaram. De maneira geral, quase todos nós nos propúnhamos, primeiro, a decifrar a esfinge do autoritarismo. Estudamos a temática do autoritarismo, depois estudamos a transição, e agora estudamos a consolidação democrática. Da perspectiva da Sociologia, a questão é menos clara. Também aqui há conexões muito íntimas com a vida política nacional, mas a identificação temática é menos óbvia. Acho ainda que é preciso pensar a questão não apenas da perspectiva da oferta, mas também da perspectiva da demanda de pesquisa. Muitos dos temas da Sociologia surgiram em resposta a uma demanda. A título de exemplo, pensando na origem da Anpocs, lembro que há cerca de 20 anos atrás surgiu uma grande demanda — ou uma produção incentivada - por estudos de gênero. Outra temática incentivada nessa mesma época foi a da saúde.

É preciso lembrar também que, lamentavelmente, alguns temas perderam espaço na investigação sociológica. Por exemplo, os estudos sobre estratificação e mobilidade social, tema clássico na Sociologia, e que no Brasil tinha uma certa tradição. A área foi perdendo espaço. Existem honrosas exceções, mas hoje pouca gente trabalha com esse tema na comunidade dos sociólogos. Considerando que contamos, no Brasil, com uma fonte de informação sistemática excelente que é a PNAD, é pena que não a utilizemos mais intensamente.

Acho que o declínio dos estudos quantitativos tem um pouco a ver com isso. Hoje em dia temos muito mais ensaios sociológicos. Há mais trabalho de tipo artesanal. E estudar estratificação social dessa perspectiva é, de fato, impossível. Este é um aspecto que acho muito importante. Acho que a idéia de trabalho de equipe se perdeu um pouco, muito em função de adversidades no que diz respeito ao financiamento de pesquisas, mas também por uma inclinação nossa. Quer dizer, de certa forma, nós temos uma tradição ensaísta que sobre vive. Redefinida, modernizada, dialogando com a bibliografia do presente, mas um certo ensaísmo que é quase uma marca registrada nossa. Acho que isso é bom por um lado, porque permite muita originalidade, mas, por outro lado, deixa lacunas.

Seja como for, é importante lembrar que, do ponto de vista da definição temática, as influências são mais claras no caso do financiamento externo. As fundações e instituições estrangeiras que financiam pesquisa dizem à sua clientela brasileira quais são os temas que lhes interessam. Nem sempre há uma opção tão estreita por tal ou tal tema, mas há uma definição de parâmetros. Enfim, elas dizem que tipo de estudo lhes interessa financiar, o que é perfeitamente legítimo. 
No que diz respeito às instituições nacionais não se dá o mesmo. Ressalvadas definições muito genéricas de temas prioritários, não há uma definição de linhas de pesquisa "financiáveis".

Fabio W. Reis - A questão da obsessão com o "contexto brasileiro", que tende a ser teoricamente insensível ou míope, tem um desdobramento relevante. É claro que o interesse em diagnosticar a realidade brasileira é parte legítima e importante da motivação de muitos estudos, que não estão condenados a ser de qualidade pobre por causa disso. As áreas temáticas novas de que a gente falou no começo, por exemplo (os estudos institucionais, eleitorais etc.), com frequência pretendem apreender especificidades brasileiras, ou fazer o diagnóstico das condições brasileiras, relativamente aos problemas de que tratam. Mas isso não impede que o trabalho que se vem fazendo em algumas dessas áreas seja exemplo de trabalho analiticamente orientado e que foge ao modelo negativo que destaquei antes.

Um primeiro aspecto, aqui, é o de haver alguma preocupação comparativa, ou seja, até que ponto o Brasil é tomado, como eu disse antes, como um caso entre outros quanto aos problemas em questão. Mas, além disso, há o fato de que a realização do diagnóstico a respeito de uma unidade singular qualquer pode envolver a necessidade de trabalho de tipo perfeitamente nomológico e generalizante a respeito de unidades de nível inferior que fazem parte dela. Fazer uma boa sociologia eleitoral do Brasil, por exemplo, supõe que se possa fazer a caracterização adequada de tipos diversos de eleitores brasileiros de acordo com toda uma série de variáveis que podem ser relevantes (sua classe social, sua origem rural ou urbana, seu grau de informação, de envolvimento político, sua ideologia etc.), e eventualmente que se possam estabelecer as relações entre diferentes categorias de eleitores, ou entre eleitores e partidos ou líderes, no processo eleitoral. Da mesma forma, o estudo do legislativo que vem sendo realizado com êxito por alguns dos nossos colegas supõe a caracterização de matérias diversas que são objeto de deliberação, o exame da maneira como se comportam os congressistas de diferentes partidos nessa deliberação, das relações que se estabelecem entre os poderes executivo e legislativo etc. Estudos desse tipo estão longe de se esgotar, portanto, na descrição: ao contrário, são estudos proposicionais, dão origem a proposições que contêm afirmações gerais a respeito de regularidades a serem observadas no comportamento de diversas unidades de análise e que podem vir a ser corroboradas ou falseadas pela observação dos dados pertinentes, além de se mostrarem relevantes e instrumentais para a preocupação de eventual comparação sistemática do que ocorre no "contexto brasileiro" com o que ocorre em outros contextos.

Uma questão diferente é a que Merton chamava de "orientações gerais", os postulados substantivos de tipos diversos (especialmente sobre a "natureza última" da realidade social) que estão, naturalmente, sempre presentes no trabalho dos cientistas sociais e costumam ter claras implicações normativas. Essa questão é de interesse porque é uma espécie de dimensão recôndita de certos debates que se pretenderiam meramente teóricos ou analíticos, tendo desdobramentos para o papel do cientista social como analista versus o impacto social do que ele faz. Uma área ilustrativa das dificuldades de alcance teórico-metodológico que surgem aqui é a dos debates sobre a "cultura política" como tema, ou dos valores cívicos que seriam necessários para a democracia autêntica ou consolidada, por contraste com o egoísmo dos interesses. Naturalmente, esse é um tema problemático mesmo na fronteira do debate internacional da atualidade, onde ocorre, por exemplo, o desafio de como lidar em termos analiticamente adequados e apropriadamente "realistas" com a questão de como erigir instituições capazes de durar, as quais, na perspectiva convencional a respeito, supõem a internalização de normas e valores por parte das pessoas envolvidas. Não creio que a gente tenha tido respostas satisfatórias sobre essa indagação, nem mesmo nos esforços de cientistas sociais de renome mundial, um Adam Przeworski, por exemplo, que se tem ocupado dela com insistência. Mas a razão de destacar o tema aqui é que, no caso do Brasil, os trabalhos a respeito tendem a misturar a análise com a exortação, ou a substituir a primeira pela segunda, com uma candura que se torna até desfrutável. Assim, a análise das 
condições da realidade a respeito e a eventual formulação de recomendações atentas para essas condições (como, efetivamente, obter a transição da precariedade institucional para a democracia autêntica, dadas as condições) se vêem substituídas por um estilo de discussão que se satisfaz com contrapor os traços supostamente deficientes da realidade a um modelo idealizado da vida política e acrescentar edificantes exortações no sentido de que nós brasileiros nos transformemos de maneira a nos aproximarmos do modelo - presumivelmente através da reforma moral ou ideológica da coletividade, ou da conversão coletiva. Um exemplo marcante é o de certas discussões sobre o velho tema de nossa suposta tendência à "conciliação", as quais, apesar de se pretenderem orientadas por postulados realistas baseados no cálculo de interesses, terminam por convidar, comoventemente, as elites brasileiras a competir para vivificar a democracia no país. Naturalmente, omite-se a ponderação de que, se as elites "conciliam", é provavelmente porque a conciliação "paga", como deveria imaginar ou hipotetizar a orientação que destaca os interesses: se paulistas e mineiros podem se entender e administrar o país com o benefício de ambas as partes na política do café-com-leite, por que competir ou eventualmente brigar? Creio que, em alguma medida, uma disposição edificante desse tipo está também subjacente à tese da democratização da cultura política brasileira que tem sido defendida pelo José Álvaro Moisés: não creio que os dados dele sejam adequados para sustentar essa tese, que se choca com dados que vão em direção diferente, incluindo alguns que eu próprio tenho estado analisando e divulgando.

Gilberto Velho - Em minha opinião, o que temos vivenciado hoje em dia é a ampliação do campo da Antropologia. A disciplina, atualmente, não encontra barreiras em termos do que pode ou não estudar. A Antropologia pode se debruçar sobre qualquer tema, seja social, seja cultural. Nós ainda somos de uma geração - eu e meus colegas que formaram as primeiras turmas de alunos de Antropologia Social do Museu Nacional - que encontrou divisões disciplinares mais rígidas. Mesmo dentro da Antropologia, as divisões de áreas de estudo eram claramente estabelecidas. Ainda havia uma forte marca, digamos assim, dos estudos indígenas e uma certa resistência, por parte de algumas pessoas, em perceber que o estudo da sociedade moderna complexa contemporânea era uma área que a Antropologia podia e devia realizar. Hoje em dia esse impasse foi superado. Nós mantemos muitas linhas de pesquisa estudando fenômenos variados, mantemos as pesquisas na área indígena, assim como os estudos rurais e camponeses. Além disso, a área urbana, que pesquisa a cidade, com seus vários tipos de comportamento, vida social, religião, política, é cada vez mais uma área abrangente. Não se trata de estudar apenas o tradicional, o antigo, mas sim de pesquisar as inovações, a globalização, os novos intercâmbios, as novas sociabilidades etc. Enfim, em minha opinião a Antropologia é, hoje em dia, uma disciplina muito mais abrangente, muito mais ampla, e isso favoreceu, por sua vez, contatos e intercâmbios mais intensos com outras disciplinas.

Em períodos anteriores, a Antropologia brasileira era composta de grupos mais fechados e auto-referidos. As reuniões que nós fazíamos no Museu, por exemplo, eram muito restritas e pequenas. Predominava a etnologia, alguns estudos de minorias e algumas pesquisas sobre o meio rural. Quase não se comentava sobre a antropologia urbana. Lembro-me bem que, naquela época, nos primeiros trabalhos de antropologia urbana, quando eu e outros colegas apresentávamos o resultado de nossas pesquisas, havia alguma desconfiança no ar por parte de pesquisadores mais tradicionais. Hoje em dia isso passou. E passou devido às nossas próprias iniciativas. Iniciativas dos antropólogos brasileiros, de novas gerações que, com maior ou menor intercâmbio com outros centros, caminharam nessa direção. E nesse sentido posso dizer, sem ufanismo, que a Antropologia brasileira é das mais importantes do mundo. Tem um papel pioneiro em termos de abertura de campos, de novas fronteiras, de novos objetos. Temas e trabalhos que aparecem como a grande novidade nos países chamados de Primeiro Mundo não diferem demais de pesquisas que estamos realizando há muito tempo. Refirome basicamente ao estudo da própria sociedade, da 
sociedade brasileira, e dos grupos a que o pesquisador está ligado ou de que participa de alguma maneira. Esse campo, que era considerado uma coisa altamente herética e heterodoxa, hoje em dia já aparece em vários centros mais tradicionais de estudos antropológicos como uma área não só aceitável como louvável e importante. Eu acho que a Antropologia brasileira tem esse papel pioneiro de buscar e criar novos objetos de investigação, seja por meio do trabalho de pesquisa de campo, seja pela utilização da literatura antropológica para investigar fenômenos das mais diferentes naturezas. Enfim, todas as manifestações do pensamento e da atividade humana que você possa imaginar são passíveis de reflexão antropológica.

É claro que a abertura da Antropologia para o diálogo com outras disciplinas, com pessoas de outras áreas, também foi muito importante. Estou me referindo não só à cooperação com a Sociologia e a Ciência Política, que, de certa maneira, é mais natural (com todas as aspas que você quiser). Fora desses limites o debate tem sido, também, muito profícuo. Acho particularmente estimulante o contato que se tem estabelecido entre a Antropologia e a História. Acredito que as duas disciplinas têm se impregnado reciprocamente e isso tem sido muito bom e importante.

A Antropologia não é uma disciplina que vive de objetos paroquiais. Ao contrário, trabalha com questões centrais relacionadas à teoria da cultura e às relações entre indivíduo e sociedade. Analisa a continuidade e descontinuidade da vida social, a problemática da reciprocidade e da troca. Investiga universos simbólicos. A Antropologia tem uma problemática mais do que complexa e explicitada de várias maneiras, sempre referida à sua forte base empírica. Eu acho que existem pessoas que ficam muito presas a uma determinada concepção, meio normativa, do que deva ser ciência social, e não percebem que existe um outro tipo de produção de conhecimento, e que essa produção está amparada em determinadas questões teóricas fundamentais. Em minha opinião, a Antropologia brasileira parte de problemáticas teóricas das mais complexas e densas, basicamente relacionadas à teoria da cultura e ao tema das relações entre indivíduo e sociedade. Esses trabalhos, por sua vez, têm sido uma produção das mais ricas e que percorre todas as áreas da Antropologia, marcada por sua tradição de trabalho de campo e observação participante.

A Antropologia, em função, sobretudo, da dimensão comparativa com que estuda as sociedades e culturas, e em nome da preocupação em perceber os significados próprios a cada cultura e o sentido de relativizar - a velha palavra continua sendo absolutamente verdadeira —, acabou fatalmente criando uma visão mais cosmopolita e abrangente do que a Ciência Política e a Sociologia mais convencionais. No entanto, esse não é um privilégio. Os melhores sociólogos e cientistas políticos são intelectuais que, de alguma maneira, participam dessa visão enriquecedora que não é propriedade exclusiva da Antropologia. Essas preocupações da Antropologia, essa visão crítica, muitas vezes é classificada de maneira pejorativa como "ensaísmo". No entanto, na realidade, esse tipo de estudo já faz parte dos primeiros trabalhos fundadores das ciências sociais, dos clássicos como Weber, Simmel, Durkheim e Marcel Mauss. Esse ensaísmo é, ao lado das monografias, um dos instrumentos que se tem para testar idéias, para aprofundar questões, para levantar problemas. A Antropologia desenvolve uma tradição, tem uma tradição própria que se vincula justamente a essa experiência de lidar com mundos diferentes — atitude essa que as pessoas que têm uma posição um pouco mais fechada não entendem. Isto é válido tanto pensando em termos de culturas diferentes — seja falando de Bali, dos Estados Unidos, da Inglaterra, ou de tribos indígenas brasileiras - como priorizando uma visão da própria sociedade, em que você percebe a existência de diferentes mundos, de múltiplas dimensões e descontinuidades. Eu tenho a impressão de que a ciência social que enfatiza tanto um certo tipo de metodologia formalista na realidade apresenta uma visão linear dos fenômenos sociais, tem uma visão esquemática e preconcebida da vida social. Destacar a descontinuidade, a multiplicidade, é justamente a marca da Antropologia, mas isso não é propriedade dos antropólogos. Repito: os melhores sociólogos e cientistas políticos fazem o mesmo em suas pesquisas. O bom cientista social é aquele que percebe as nuanças, os matizes, 
as mudanças de plano, as mudanças de nível, que não podem ser captadas por meio de esquemas e visões lineares do fenômeno social.

\section{Impactos das ciências sociais na sociedade nacional}

Elisa Reis - Quanto a esse aspecto, gostaria de salientar sobretudo a questão da relevância política e da relação com a democratização. Creio que essa é uma característica marcante da ciência social brasileira: estamos o tempo todo desempenhando alguma missão nacional. É assim que tendemos a ver nosso exercício profissional. Pessoalmente, valorizo isso. Certamente porque estou inserida nessa cultura. Acho que se há uma coisa que nos une, que realmente faz de nós uma comunidade de cientistas sociais no Brasil, um dos aspectos mais fortes da nossa prática, é essa forte identificação que temos com a causa nacional. $\mathrm{O}$ que é curioso, já que muitos de nós estamos estudando o declínio do nacionalismo. E, de fato, a idéia do nacionalismo já perdeu muito espaço. Mas, até mesmo como categoria social, como intelectuais, continuamos, de uma certa forma, pensando em nossa missão nacional, em nossa obrigação diante da sociedade brasileira. Que contribuição podemos dar? Talvez eu me engane, mas na interação com colegas estrangeiros e na experiência de ensinar fora do Brasil, acho que essa dimensão é muito mais presente para os cientistas sociais brasileiros do que para muitos outros.

Fabio W. Reis - Como eu disse antes, essa questão das áreas temáticas está ligada à questão da "relevância" das ciências sociais, ou de seu impacto sobre a socidade. Muito do que se faz na atividade profissional dos nossos cientistas sociais pretende justificar-se por uma preocupação de engajamento social ou mesmo, às vezes, de militância política. Naturalmente, não há nada de errado em que a motivação última seja dessa natureza, e é certamente inevitável e bom que haja algo disso. Mas o problema consiste em que, com muita freqüência, o sentimento da relevância do que se faz, nesse sentido, ou da importância e premência sociais dos problemas tratados, é tomado como algo que dispensa maiores preocupações com a qualidade do trabalho em termos dos objetivos analíticos e de produção de conhecimentos. Por outras palavras, com freqüência se encontra, mesmo entre cientistas sociais sofisticados, a posição de que as relações entre preocupações de qualidade e de relevância deveriam ser relações de equilíbrio ou compromisso, num trade-off em que um aumento de relevância justificaria uma perda correspondente de qualidade. Creio que isso é um erro. $\mathrm{Na}$ minha maneira de ver, as relações entre os dois aspectos são de tipo lexicográfico: problemas de relevância só se colocam uma vez que a qualidade esteja assegurada (assim como, ao ordenar alfabeticamente um conjunto de nomes, só prestamos atenção à segunda letra que compõe cada um depois de termos dado a devida precedência à primeira letra). Caso contrário, corremos o risco de sermos inundados por estudos supostamente "relevantes" que, na verdade, não nos ensinam nada sobre os problemas tratados, ou que ajudam mais a confundi-los do que a esclarecê-los. É bom lembrar que, quanto mais socialmente relevante e premente o problema, tanto mais ele será objeto de debate entre os leigos: na condição de cidadão, e com todo o direito, todo mundo vai se interessar pelo problema e ter palpites a dar sobre ele. Ora, a contribuição das ciências sociais tem de ser uma contribuição que se distinga pela força analítica e pelo interesse intrínseco do conhecimento trazido, e não pode ser uma contribuição em que os palpites do cientista social bem-intencionado simplesmente compitam em igualdade de condições com os palpites do leigo. É claro, temas como fome, criminalidade, violência, de grande dramaticidade prática, estão especialmente expostos ao perigo desse tipo de confusão, povoando-se de cientistas sociais indignados que, com freqüência, se dão por satisfeitos em expressar reiteradamente a indignação que compartilhamos todos. Veja o exemplo do Núcleo de Estudos sobre a Violência da USP: podemos saber pouco ou nada sobre o conhecimento por ele produzido (que pode até ser muito meritório), mas somos regularmente expostos a suas manifestações indignadas de repúdio à violência dos violentos. Ou, para 
tomar outro exemplo em que as coisas são mais evidentes: é claro que quem fazia campanhas contra a fome não era propriamente o sociólogo Herbert de Souza, mas o Betinho, cidadão e líder.

Gilberto Velho - Existe uma coisa chamada produção de conhecimento. Eu creio que a produção do conhecimento é um fim em si mesmo. Conhecer a sociedade em suas diferentes manifestações, em suas várias instâncias, nas suas tradições, nas suas inovações, nas suas ambigüidades, nas suas contradições, nos seus conflitos, esse é um fim em si mesmo. Conhecer, conhecer. Em qualquer área o conhecimento se justifica. Então, eu não consigo instrumentalizar o conhecimento nesses termos. Agora, evidentemente, a produção de conhecimento na área social permite que alguns cientistas, alguns antropólogos, se debrucem mais sobre problemas e sobre questões que podem ter uma relevância mais imediata em termos dos dramas e das grandes questões da sociedade contemporânea. Na verdade, o movimento tem mão dupla: ou os próprios cientistas sociais podem se debruçar sobre esses problemas, podem enfrentá-los, podem procurar encaminhá-los, ou as pesquisas que produzem, os textos que escrevem, os temas que pesquisam podem ser usados por outros indivíduos, por outros grupos, por outras categorias profissionais.

A Antropologia traz pontos de vista, perspectivas e experiências que enriquecem o debate sobre a sociedade. É só perceber a manifestação dos antropólogos na mídia, escrevendo artigos, dando depoimentos, seja nos jornais, nas revistas, na televisão ou no rádio. Esse ponto de vista antropológico, essa perspectiva da Antropologia, procurando ver as coisas em seus contextos, procurando trazer algumas idéias ligadas à sua experiência de relativização e de estranhamento, tem tomado um novo vulto, para além dos muros da academia. A busca de uma visão mais crítica, de desnaturalizar idéias, conceitos e enfrentar preconceitos tem chamado a atenção. Dessa maneira, os antropólogos vêm desempenhado um papel importante no sentido de denunciar preconceitos, de chamar a atenção para a complexidade de fenômenos que parecem, ao senso comum, tão transparentes. Esse diálogo com o senso comum, não para anulá-lo, nem para humilhálo, mas para ir adiante, para recuperá-lo, tem sido constante.

A Antropologia está, portanto, muito ligada a essa idéia, tão em moda, do diálogo. Mas o diálogo que parte, exatamente, da constatação das diferenças. Não para congelá-las, mas para permitir que, mediante seu reconhecimento, seja possível haver diálogo, reconhecimento, interação no sentido mais amplo.

A Antropologia representa, dessa forma, uma voz de exceção nesse grande diálogo sobre a globalização. Eu acho que a Antropologia - e não é à toa que as pessoas ligadas a esquemas modernizantes, ditos globalizantes, implicam com ela - chama a atenção para a diferença, para o específico, para a singularidade. Recusa a uniformidade, critica as visões homogeneizadoras, critica a visão evolucionista esquemática, linear. Então, a Antropologia está o tempo todo incomodando, chamando a atenção para a limitação dos esquemas fáceis. A disciplina acaba desempenhando, mesmo que não intencional e explicitamente, o papel de sustentar a bandeira do pluralismo sociocultural, que é, por sua vez, uma realização da diversidade. Ao tomar para si esse papel, a disciplina tem batido de frente com economistas e outros cientistas sociais que têm uma visão mais uniformizadora, mais homogeneizadora e pretensamente universalista. Eu diria que aí residiria um falso universalismo, não só da sociedade, como do gênero humano. É bom lembrar também as diversidades internas da Antropologia, com várias linhagens e pontos de vista eventualmente contraditórios.

\section{Principais problemas e perspectivas das ciências sociais brasileiras}

Elisa Reis - Creio que nas observações anteriores já me detive na consideração de nossos problemas e nossas perspectivas. Gostaria apenas de voltar às minhas observações iniciais quanto à perplexidade radical que vivem hoje as ciências sociais em geral e a Sociologia em 
particular. Quando nossos conceitos fundantes não cumprem mais o papel de estruturar nosso pensamento, ou quando só ainda o fazem de forma muito segmentada, é sinal de que a confusão está instalada. Perceber essa confusão de forma positiva ou negativa é, em grande parte, uma opção epistemológica. De minha parte, faço a aposta tradicional no potencial revitalizante da crise.

Gostaria apenas de concluir enfatizando que os 20 anos de Anpocs são parte de uma história de muitos desafios, muita ousadia e muita criatividade nas ciências sociais brasileiras.

Fabio W. Reis - É certo que construímos muita coisa. Hoje existem programas que representam realizações importantes. Mas os resultados com freqüência ainda deixam a desejar.

Acho que estamos num momento incerto, em vista das conseqüências equívocas do diagnóstico que esbocei precariamente. Não sei se o futuro é brilhante. Obviamente vai haver sempre pérolas. A questão é saber se teremos coisas boas em quantidade suficiente, em correspondência com o esforço que afinal de contas se fez para criar a pósgraduação e institucionalizar as ciências sociais como campo de trabalho acadêmico. Acho que desse ponto de vista se justifica uma aposta precavida.

Não acho que falta de recursos seja ou tenha sido o nosso problema principal. Não é de hoje que minha experiência com diversas instituições de fomento e amparo à pesquisa me convenceu de que, na verdade, ao invés de nos faltar financiamento, temos sido sobrefinanciados: não só os projetos ou propostas que têm algum mérito têm condições de obter financiamento, como também financia-se muita coisa que não tem mérito. Desse ponto de vista tem havido, portanto, uma certa sobra de recursos.

Creio que o problema crucial é o da apropriada institucionalização das ciências sociais que acabo de mencionar. Não chegamos a realizar direito essa institucionalização, no sentido de que não criamos fóruns reais de comunicação, de crítica recíproca, de debate conseqüente, de filtro e seleção. Não estabelecemos mecanismos orientados de maneira mais efetiva para aperfeiçoar ou melhorar a qualidade de nossa produção científica. A precariedade da institucionalização se manifesta, por exemplo, em certos aspectos do funcionamento da Anpocs (a qual certamente é, em princípio, uma evidência gritante de êxito dos esforços que se vêm fazendo): refiro-me à grande dose de ritualismo que a gente encontra nos debates dos grupos de trabalho. Embora imagine que haja exceções (e embora eu mesmo tenha tido a experiência de colaboração proveitosa com colegas em outras circunstâncias), o fato é que participei de vários grupos de trabalho da Anpocs e, apesar de me ter envolvido com empenho (e ocasionalmente com alguns custos pessoais) nas discussões e na avaliação crítica dos trabalhos dos demais, nunca vi qualquer resultado desse esforço crítico: nunca fui testemunha de algum caso em que alguém reformulasse o que quer que tivesse levado para as discussões, ainda que fosse para, diante da crítica, sustentar as mesmas posições anteriores com argumentos novos. Nunca! É claro que a cultura que aí transparece tem conseqüências importantes do ponto de vista dos critérios que presidem a política de publicações na área, mesmo pondo de lado as considerações de tipo comercial que podem surgir aqui e tomando apenas a medida em que a política de publicações é influenciada por decisões do próprio meio acadêmico como tal. E não admira, naturalmente, que tampouco tenhamos qualquer tradição de criticar a sério o que se publica.

Mas acho que o decisivo quanto à institucionalização se sintetiza em que não chegamos a implantar uma carreiraacadêmica real na área das ciências sociais, no sentido de um ambiente institucional propício a uma trajetória na qual o sujeito seja adequadamente estimulado nos diferentes momentos ou etapas. Deve haver algo de bastante errado, desse ponto de vista, numa situação em que, à medida que se alcançam pontos mais avançados da carreira, há um incentivo à debandada e as oportunidades de diálogo produtivo com os pares vão ficando mais rarefeitas. Mas talvez se trate aqui, em alguma medida, apenas de lamúrias de um neovelho (se o "neo" tem 
cabimento), aposentado e recém-transformado em professor emérito.

Gilberto Velho - Acredito que estejamos passando por uma séria crise nas ciências sociais. Essa crise está relacionada à política nacional, de forma mais geral, em termos da concepção do que seja uma estabilidade econômica e de uma visão da função do Estado. Eu acho que é muito difícil, hoje em dia, avaliar positivamente esse conjunto de medidas, porque nos afetam de uma maneira muito dura, em termos dos nossos planos e projetos. De uma forma geral, é muito complicado ter políticas públicas, em qualquer área. No entanto, nas atividades científicas e universitárias essas medidas são absolutamente essenciais: não há desenvolvimento sem uma expectativa mínima de recursos estáveis e regulares. Com relação a esse aspecto, há uma grande diferença entre as instituições de São Paulo e as instituições de fora de São Paulo. As instituições de São Paulo têm um pouco mais de segurança em função, sobretudo, da FAPESP. Existe uma estrutura universitária estadual e, além dela, a FAPESP, que desempenha um papel muito importante, embora as instituições paulistas também dependam do apoio das agências federais.

Não obstante, no caso das instituições públicas federais, de fato ocorre uma situação bastante dramática, na medida em que existe - devido ao gerenciamento de recursos aplicado pelos ministérios da Fazenda e do Planejamento - um bloqueio de fluxos de apoio, fazendo com que as atividades de pesquisa e pós-graduação fiquem realmente prejudicadas. Refiro-me não só às taxas de bancada do CNPq e da CAPES, como aos recursos do Fundo Nacional de Desenvolvimento Científico e Tecnológico — o famoso FNDCT - , ou aos meios da universidade em geral. Neste momento, as universidades públicas federais - como a UFRJ, que é a maior de todas as federais e vive esse processo de um modo muito intenso — não têm dinheiro para pagar as contas de luz, para pagar seus fornecedores, para pagar a limpeza. Então, a situação é, no mínimo, paradoxal: vivemos sob um regime democrático, um governo em que eu, por exemplo, votei, fiz campanha e apóio, mas que de fato está fazendo com que as universidades paguem um preço muito alto com essa política de modernização, de restrição de gastos, de acerto da economia... Parece-me que o governo vem cometendo um grave erro, na medida em que essas conquistas todas, desses 20 e poucos anos, que permitiram a criação de quadros competentes, que desenvolveram uma tradição de ensino pós-graduado e de pesquisa, estão sendo de fato ameaçadas. Eu tenho dito isso, tenho falado sobre isso, tenho escrito sobre isso e, sempre que posso, falo inclusive com o Presidente da República.

Com relação ao Museu Nacional, local onde leciono e pesquiso, no caso específico da Antropologia, no momento estamos vivendo um problema sério. Dependemos muito da Finep, que é uma agência que nos tem apoiado há bastante tempo e assumido uma importância crucial. Por exemplo, temos um projeto aprovado, mas existe um problema de liberação de recursos. Resultado: as pesquisas são prejudicadas e surge o problema de retardo das atividades. Por outro lado, outras agências também sofrem percalços. Com relação ao $\mathrm{CNPq}$, houve a suspensão das taxas de bancada durante algum tempo, o que causou prejuízos e atrasos. Isso para não falar das constantes ameaças de suspensão e corte das bolsas. Existe, portanto, um clima de intranqüilidade, um clima de ansiedade, que em nada ajuda o trabalho científico e o trabalho de ensino. Julgo tudo isso muito desgastante. Porém, acredito que hoje estejamos vivenciando esse impasse como mais um paradoxo: na verdade, temos de usar muito de nosso tempo na luta por recursos, na batalha por garantir coisas mínimas, coisas básicas. Até então acreditávamos que devíamos estar utilizando esse mesmo tempo para ensinar, dar aula, fazer pesquisa, enfim, para desenvolver atividades acadêmicocientíficas. Na realidade, aquele modelo de intelectual que pesquisa, que lê, que conversa com seus alunos num certo clima de serenidade, de produção intelectual, num ritmo, digamos assim, mais harmonioso está cada vez mais afastado da realidade. O que vemos hoje em dia são pessoas que correm de um lado para outro, freneticamente, tentando dar conta de suas atividades, lutando por recursos, lutando contra a burocracia, contra os atrasos. Apesar de tudo isso, é importante que se diga que eu continuo acreditando que chegamos a um patamar de excelência e de 
qualidade na pós-graduação (e mesmo nessa relação integrada entre pesquisa e pós-graduação) difícil de reverter. Atingimos esse patamar de qualidade. Eu acho que isso ocorre nas ciências sociais em geral. No caso da Antropologia do Museu Nacional, atingimos esse patamar de qualidade e temos conseguido mantê-lo e, em alguns níveis, até melhorá-lo. Porém, o clima, o entorno, é muito ruim. A situação, não do Museu, não especificamente da Antropologia Social, mas da universidade pública em geral é muito grave. O Museu Nacional faz parte da Universidade Federal do Rio de Janeiro e esta instituição vive, sem dúvida, uma crise muito grande, que nos afeta diretamente.

Concluindo, se sob certos aspectos a nossa situação melhorou muito — vivemos num regime democrático, não estamos ameaçados pelo DOI-CODI, não temos sempre medo de sermos presos a qualquer hora, nem nós nem nossos alunos, não conhecemos a mesma corrupção do período Collor etc. - , no entanto, a política econômica imperante está afetando de modo muito danoso a universidade e a pesquisa científica como um todo

A Antropologia, como disciplina, atravessa um bom momento e trabalha em muitas frentes. Não dá para dizer que exista uma área predominante no momento. Em minha opinião, o que existe é uma recuperação da noção de cultura. Sofisticando mais a discussão sobre a teoria da cultura, nós estamos fazendo com que se perca, de certa maneira, uma antiga divisão entre Antropologia Social e Antropologia Cultural. Acho que hoje em dia a Antropologia é cada vez mais Antropologia, dialogando com teorias da cultura e com teorias sociológicas. Acho que isso é um avanço. Isso é um produto, justamente, das novas pesquisas e trabalhos, do atual amadurecimento da disciplina e da área. E com isso aparecem, realmente, muitas frentes. A Etnologia continua desempenhando um papel crucial, permitindo avanços teóricos e pesquisas importantes no Brasil e no mundo. Acredito também que o estudo da própria sociedade realmente tem aberto muitas perspectivas, muitas possibilidades, não só porque permite a análise de grupos mais ou menos próximos, mas sobretudo na medida em que permite levantar questões interessantes sobre simbolismo, sobre rituais, sobre relações interétnicas e sobre a própria natureza da produção de conhecimento. Aí está outro lado fascinante da disciplina, que avalia a própria produção do conhecimento em suas dimensões simbólicas, econômicas, organizacionais.

Outro movimento importante é esse que tem aproveitado uma tradição já existente — a tradição de estudos sobre camadas populares, cultura popular e folclore. A partir desses temas é possível estabelecer pontes e relações entre diferentes níveis de cultura — nos termos de Peter Burke e Bakhtin -, recuperando noções como fato social total, a idéia de sistemas de trocas, de sistemas de reciprocidade. Com isso é possível desenvolver estudos sobre as relações entre diferentes categorias existentes numa sociedade, no caso, complexa. Ou seja, não é preciso permanecer nos estudos de grupos mais fechados e de tradições mais específicas (embora isso continue sendo importante); ao contrário, tem-se procurado ver sobretudo as relações entre essas diferentes categorias e tradições Enfim, eu acho que existem várias áreas de atuação. A problemática tradicional indivíduoversus sociedade tem sido reinventada, rediscutida, mediante a contextualização de diferentes concepções e ideologias ligadas à tensão entre individualismo e hierarquia, individualismo e holismo etc.

Por fim, há sempre uma releitura dos clássicos que, de fato, são sempre atuais. Eles estudaram relações entre sistemas, viram sistemas em transformação, viram a sociedade como processo, procuraram analisar as bases mais profundas da vida social. Com diferentes perspectivas, com diferentes conceitos, estavam voltados para relações entre mundos, grupos e códigos variados, procurando entender a lógica dessas relações.

A alteridade, sem ser reificada, foi sempre a grande questão da Antropologia. Por outro lado, a problemática urbana contemporânea vem fazendo com que a noção de alteridade também seja revista, a partir de investigações inovadoras.

Parece-me que a dinâmica das relações sociais e esse modo de ver a sociedade como um conjunto - não 
necessariamente articulado, certamente não linear, mas um agregado de diferentes mundos, de diferentes níveis, de diferentes qualidades de experiência - fazem com que a noção de alteridade transforme-se em uma noção mais complexa e sutil. O trabalho de campo prossegue como característica fundamental da disciplina, incentivando reavaliações e críticas inovadoras.

Outro ponto que deve ser ressaltado é que o desenvolvimento das pesquisas não deve ser vinculado exclusivamente à política oficial de financiamento, mas também à política das associações científicas. Acho que as duas coisas caminham juntas. O poder público, por meio de suas agências, apresenta um perfil contraditório, com altos e baixos, produzindo um clima de ansiedade e sustos. Dependemos essencialmente dele, mas é necessário manter uma postura que garanta um mínimo de independência e visão crítica. Creio que a atuação da Anpocs, da SBPC, da ABA etc. vem permitindo um maior contato, um maior intercâmbio entre grupos espalhados pelo país, não só de universidades diferentes como de áreas disciplinares distintas. Na minha opinião, não se pode subestimar - e no caso da Anpocs essa é uma atitude, inclusive, deliberada - esse papel. As sociedades científicas ocupam um lugar crucial no sentido de permitir a circulação e o intercâmbio, e essa atuação funciona como uma espécie de motor. $\mathrm{Na}$ realidade, o apoio financeiro do setor público, do governo, caminha pari passu ao desenvolvimento das iniciativas das sociedades científicas, que são expressão dos programas e dos profissionais da área.

Eu não sou muito normativo nessas coisas: perspectivas, caminhos etc. O que eu diria é que a Antropologia, como disciplina, vai muito bem. Ela tem problemas sérios, devido às questões mais gerais do país, às questões de que falamos no início: a dificuldade de recursos, a inconstância de apoio, a crise da universidade. Agora, a disciplina, como posição no campo de produção do conhecimento, tem uma atuação relevante. Isso tudo porque é aberta, porque é abrangente, porque é pluralista, porque é crítica e porque é receptiva. Se nós perdermos isso, começarmos a nos fechar em posições muito consolidadas, em posições de muita auto-satisfação...
Quando elogio a Antropologia no Brasil, quando reconheço que a disciplina no país está bem, não significa adotar uma posição meramente ufanista. Faço questão de dizer que não. O que existe de bom é essa possibilidade de manter uma abertura, que tem a ver, ao mesmo tempo, com uma certa combinação de ousadia e humildade da disciplina. Não se trata de estimular, em nenhum momento, uma postura triunfalista e arrogante. Ao contrário. A Antropologia só pode ser produtiva, só pode continuar sendo estimulante e criativa se mantiver aberturas: antenas ligadas, aberturas para outros países, para outros centros, para outras áreas do conhecimento. Então é isso. Eu acho que essa perspectiva crítica, não dogmática e aberta, não só para linhas de conhecimento científico mais convencionais, mas para outros caminhos como a produção artística, a reflexão filosófica, por exemplo, é o que mantém a Antropologia viva e atuante. 